\title{
El indulto en el proceso de Independencia de la Nueva Granada, 1808-1821
}

Pardon in the Independence Process of New Granada, 1808-1821

Le pardon dans le processus d'indépendance de la Nouvelle-Grenade, 1808-1821

\section{Jairo Antonio Melo Flores}

\section{(2) OpenEdition}

\section{Journals}

\section{Edición electrónica}

URL: http://journals.openedition.org/rhj/612

DOI: $10.4000 /$ rhj.612

ISSN: 0719-4153

\section{Editor}

ACTO Editores Ltda

Referencia electrónica

Jairo Antonio Melo Flores, «El indulto en el proceso de Independencia de la Nueva Granada

1808-1821 », Revista Historia y Justicia [En línea], 6 | 2016, Publicado el 30 abril 2016, consultado el 19 abril 2019. URL : http://journals.openedition.org/rhj/612 ; DOI : 10.4000/rhj.612 


\title{
EL INDULTO EN EL PROCESO DE INDEPENDENCIA DE LA NUEVA GRANADA, 1808-1821
}

\author{
Jairo Antonio MELO FLORES (*)
}

El perdón real caracterizó a la justicia de la monarquía castellana. Al iniciar el proceso de independencia, en el Nuevo Reino de Granada, éste fue abordado, por lo general, como un mecanismo para obtener lealtades y reducir la cantidad de personas vinculadas con grupos rebeldes o con organizaciones políticas asociadas al movimiento constitucional de 1811 a 1815. De igual manera, el ejército insurgente y el gobierno provisional usaron el perdón de criminales como una manera de obtener legitimidad y procurar lealtades de los habitantes de los territorios en disputa. Este artículo explora el uso del indulto desde una perspectiva jurídica y política, para entender sus propósitos estratégicos en tanto instrumento legal empleado por las facciones en conflicto.

Palabras Clave: Nuevo Reino de Granada, Colombia, Independencia, perdón, administración de justicia

\section{Pardon in the Le pardon dans le processus Independence Process of d'indépendance de la Nouvelle-Grenade, New Granada, 1808-1821 1808-1821}

In the Spanish monarchy, royal pardon was one of the features of the justice system. In

New Granada, pardons were used at the beginning of the independence process as a mechanism to obtain loyalties and to weaken the rebel groups and the political organizations associated to the constitutional movement of 1811 to 1815 .

In a similar way, the insurgent army and provisional government resorted to the pardon of criminals as a way to obtain legitimacy and to ensure the loyalty of the disputed territories' inhabitants.

This article explores the royal and republican pardon from a legal and political perspective, to show how conflicting

factions used pardon as a legal tool with strategic purposes.

Keywords: New Kingdom of Granada, Colombia, Independence, pardon, justice system
Le pardon royal caractérise la justice de la monarchie castillane. Au début du processus d'indépendance, dans le Royaume de Nouvelle-Grenade, il était entendu comme un mécanisme d'obtention de loyautés et pour réduire le nombre de personnes en lien avec des groupes rebelles ou avec des organisations politiques associées au mouvement constitutionnel de 1811 à 1815.

De la même façon, l'armée insurgée et le gouvernement provisoire utilisèrent le pardon de criminels comme manière de légitimer leur action et de fournir des sujets loyaux parmi les habitants des territoires en conflit. Cet article explore l'utilisation du pardon dans une perspective juridique et politique pour comprendre leurs objectifs stratégiques en tant qu'instrument légal employé par les factions en conflit.

Mots clé: Nouvelle-Grenade, Colombie, Indépendance, pardon, administration de la justice

Recibido: 22 de diciembre de 2015 / Aceptado: 7 de abril de 2016

(*) Estudiante doctorado en historia, El Colegio de Michoacán, COLMICH. Magister en Historia Universidad Industrial de Santander, UIS. Integrante del Grupo de Investigaciones Históricas sobre el Estado nacional colombiano, Colciencias, Colombia. jairom@colmich.edu.mx 
Revista Historia y Justicia

ISSN 0719-4153 revista.historiayjusticia.org

N6 - Santiago de Chile, abril 2016, p. 228-257

\title{
El indulto en el proceso de Independencia de la Nueva Granada, 1808-1821
}

\author{
Jairo Antonio MELO FLORES
}

Este trabajo estudia el uso de los indultos ${ }^{1}$ durante la transición entre la crisis de la monarquía de 1808 y la creación de la nación independiente de la Nueva Granada en $1821^{2}$. Se parte del presupuesto que la relación dialéctica entre castigo y perdón se vio fortalecida después de la segunda mitad del siglo XVIII, a la par de las reformas gubernativas de la monarquía borbónica. Por ello, si bien este trabajo se enmarca en los años de 1808 a 1821, se entiende que este proceso es una consecuencia no planeada de las reformas en la monarquía hispana, es decir, prestando las palabras de Antonio Annino, "consideramos que las revoluciones, desencadenadas por los hechos de Bayona, fueron una consecuencia - no una causa- de la crisis de la monarquía"3. Así mismo, la independencia política no implicó una ruptura con el orden jurídico tradicional ${ }^{4}$, mas no por negligencia de los legisladores sino por una decisión pensada y compartida, según la cual las reformas a la justicia debían realizarse de

\footnotetext{
${ }^{1}$ Este trabajo fue resultado del seminario "Ideas e instituciones políticas y jurídicas coloniales", dirigido por el doctor Rafael Diego-Fernández Sotelo, como parte del programa de doctorado en Historia de El Colegio de Michoacán (cohorte 2014-2019). Para la realización de este trabajo se contó con el apoyo de una beca de estudios otorgada por el Consejo Nacional de Ciencia y Tecnología (Conacyt) de México.

${ }^{2} \mathrm{El}$ proceso de independencia neogranadino puede dividirse en dos grandes periodos; el primero, de 1808 a 1816 es denominado el interregno, que comprende el periodo que va desde la creación de las juntas de gobierno provincial hasta la pacificación por el ejército regalista. El segundo periodo, de 1816 a 1821, está enmarcado por la guerra entre el ejército bolivariano y las resistencias del ejército y los grupos leales a la monarquía. Para una profundización en el proceso de independencia, véase Gutiérrez Ardila, Daniel, Un nuevo reino: geografía política, pactismo y diplomacia durante el interregno en Nueva Granada, 1808-1816. Universidad Externado de Colombia, Bogotá, 2010. También Martínez Garnica, Armando \& Quintero Montiel, Inés Mercedes, "La formación de los Estados republicanos en la Nueva Granada y Venezuela", Ayer. Revista de historia contemporánea, Madrid, n74, 2009, p. 77-105. 3 Annino von Dusek, Antonio, "Revoluciones hispanoamericanas. Problemas y definiciones", en González Bernaldo de Quirós, Pilar (coord.), Independencias iberoamericanas. Nuevos problemas y aproximaciones, Fondo de Cultura Económica, Buenos Aires, 2015, p. 38.

4 Garriga, Carlos, "Orden jurídico e independencia política: Nueva España, 1808-México, 1821", en Annino, Antonio (coord.), La revolución novohispana, 1808-1821, Fondo de Cultura Económica, México, 2010, p. 36.
} 
manera meditada 5 . En este sentido, se asume cambiaron los detentadores de la gracia de los indultos, pero éste mantuvo su fundamento jurídico esencial: la eliminación de la pena a uno o varios reos por la voluntad del gobernante.

Como insumo para este trabajo se recopiló documentación procedente del Archivo General de la Nación de Colombia, específicamente de la serie asuntos criminales de las secciones Colonia y República; del Fondo Quijano de la Biblioteca Nacional de Colombia, de la Real Academia de Historia de Madrid y del Archivo Histórico Nacional de España. También se hizo uso de las fuentes publicadas, como las proclamas de Simón Bolívar y las actas de los Congresos de Angostura y Cúcuta. Con esta información fue posible encontrar las cédulas y decretos de indulto dados por los gobernantes, tanto de la monarquía como de la república en dichos años, así como solicitudes de indulto de diferentes reos, cuyas peticiones aún se conservan en el Archivo General de la Nación. Las actas de los congresos constitucionales fueron de suma importancia para revelar las discusiones que se dieron al interior de las asambleas, relacionadas con las implicaciones relativas al ejercicio de la gracia de perdón por parte del presidente de la república o el poder legislativo.

Para el abordaje teórico del perdón se tomó como base el trabajo de María Inmaculada Rodríguez Flores, El perdón real en Castilla (siglos XIII-XVIII) ${ }^{6}$, en el cual se realiza una exhaustiva exploración del perdón real desde el reinado de Alfonso X hasta el de Carlos IV. El trabajo de Rodríguez, que amplía significativamente el estudio previo de Francisco Tomás y Valiente ${ }^{7}$, es de suma importancia porque en éste se analizan las características generales de la doctrina del perdón real, sus alcances y motivaciones, los requisitos para hacerse acreedor a la gracia y los efectos que conllevó el perdón para los reos y la parte ofendida.

Además, el trabajo de Rodríguez sirvió como insumo para otros trabajos que pueden considerarse hoy clásicos, como el de Abelardo Levaggi, titulado "Las instituciones de clemencia en el derecho penal rioplatense" publicado en $1976^{8}$, el cual sería un estudio pionero para el contexto del derecho penal rioplatense e indiano ${ }^{9}$. El argumento central de Levaggi consiste en considerar que "el derecho penal indiano, adoptado y adaptado desde Castilla, abrigó un sutil equilibrio entre la necesidad de vengar las ofensas por medio del

\footnotetext{
${ }^{5}$ Annino von Dusek, A., "Revoluciones hispanoamericanas", Op. Cit., p. 48.

6 Rodríguez Flores, María Inmaculada, El perdón real en Castilla (siglos XIII-XVIII), Universidad de Salamanca, Salamanca, 1971.

7 Tomás y Valiente, Francisco, "El perdón de la parte ofendida en el Derecho penal castellano (siglos XVI, XVII y XVIII)", Anuario de Historia del Derecho Español, n³1, 1961, p. 55-114.

${ }^{8}$ Levaggi, Abelardo, "Las instituciones de clemencia en el Derecho penal rioplatense", IV Congreso del Instituto Internacional de Historia del Derecho Indiano, 1976, p. 243-298.

${ }^{9}$ Agüero, Alejandro, Castigar y perdonar cuando conviene a la República: la justicia penal de Córdoba del Tucumán, siglos XVII y XVIII, Centro de Estudios Políticos y Constitucionales, Madrid, 2008, p. 145.
} 
castigo y de prevenir los crímenes por el escarmiento, por una parte, y por la otra, la de proceder con espíritu de piedad, buscando la enmienda del reo antes que su destrucción”10.

Estos trabajos pioneros se han visto enriquecidos significativamente con el paso de los años, en especial por el auge de la nueva historia del derecho, que ha prestado mayor atención a los aspectos sociales y culturales de las relaciones jurídicas ${ }^{11}$. Al respecto la obra de António Manuel Hespanha representa un marco teórico significativo para el análisis de los aspectos culturales del derecho en la monarquía corporativa, específicamente del perdón en el derecho penal, acerca del cual concluye: "Si amenazando con el castigo (pero castigando efectivamente muy poco) el rey se afirmaba como justiciero, cuando perdonaba se reafirmaba otra de sus imágenes, la de pastor y de padre, esencial también a los efectos de su legitimación"12. Tal consideración teórica ha servido de marco para los análisis de Alejandro Agüero en la Provincia de Córdoba del Tucumán de los siglos XVII y XVIII ${ }^{13}$ y para la tesis doctoral de María Victoria Montoya Gómez, sobre el caso de la ciudad de Antioquia (Nuevo Reino de Granada) para finales del siglo XVIII e inicios del XIX ${ }^{14}$.

Los indultos no han sido un tema ausente en la historiografía de la independencia, y sin embargo no han sido objeto de un estudio en profundidad. Trabajos como Repúblicas en armas de Clément Thibaud ${ }^{15}$, Cabildo, política y sociedad de Renzo Ramírez y Marta Ospina ${ }^{16}$, y El retorno del rey de Justo Cuño ${ }^{17}$, así como el clásico trabajo de José María Ots Capdequí, Las instituciones

\footnotetext{
${ }^{10}$ Levaggi, A., "Las instituciones de clemencia", Op. Cit., p. 243.

${ }^{11} \mathrm{Al}$ respecto, es relevante la apreciación de António Manuel Hespanha quien dice: "Nosotros, por el contrario, no nos cansaremos de insistir en que las prácticas de las cuales la historia se ocupa son prácticas realizadas por los hombres, es decir, prácticas que de algún modo proceden de actos de cognición, de evaluación y de volición." Hespanha, António Manuel, "La senda amorosa del derecho. Amori y iustitia en el discurso jurídico moderno", en Petit, Carlos (ed.) Pasiones del jurista: amor, memoria, melancolía, imaginación, Centro de Estudios Constitucionales, Madrid, 1997, p. 29.

12 Hespanha, António Manuel, La gracia del derecho: economía de la cultura en la edad moderna, Centro de Estudios Constitucionales, Madrid, 1993, p. 232.

13 Agüero, Alejandro, "Clemencia, perdón y disimulo en la justicia criminal del Antiguo Régimen: su praxis en Córdoba del Tucumán, siglos XVII y XVIII”, Revista de Historia del Derecho, Buenos Aires, n³2, 2004, p. 145-166.

${ }^{14}$ Montoya Gómez, María Victoria, "Los jueces y los desordenados: la administración de justicia y los esfuerzos por ordenar vistos a través de las relaciones ilícitas. El caso de la ciudad de Antioquia, 1750-1809", Tesis de doctorado en Historia, Universidad Nacional Autónoma de México, Ciudad de México, México, 2013, p. 234-238. La autora profundizó al respecto en el artículo "Castigo y perdón: el movimiento comunero. Nuevo Reino de Granada, 1781”, Mouseion, Canoas, n¹8, 2014, p. 35-53.

15 Thibaud, Clément, Repúblicas en armas: los ejércitos bolivarianos en la guerra de Independencia en Colombia y Venezuela, Instituto Francés de Estudios Andinos / Editorial Planeta, Bogotá, 2003.

16 Ramírez Bacca, Renzo \& Marta Ospina Echeverri, Cabildo, política y sociedad, 1810-1821: el caso de la provincia de Antioquia, Universidad Nacional de Colombia, Vicerrectoría General, Comisión para la Celebración del Bicentenario de la Independencia, Bogotá, 2011.

17 Cuño Bonito, Justo, El retorno del rey: el restablecimiento del régimen colonial en Cartagena de Indias (1815-1821), Universitat Jaume I, Castelló de la Plana, 2013, p. 88.
} 
del Nuevo Reino de Granada al tiempo de la independencia ${ }^{18}$, han mostrado el uso del indulto en el contexto del conflicto revolucionario. Estas investigaciones concuerdan en interpretar los decretos de indulto, promulgados por los generales de los bandos en pugna, como una acción de guerra que propendía a la desarticulación de los ejércitos rebeldes, pero también como un mecanismo para retomar la administración de justicia regia y liquidar los proyectos institucionales republicanos. Este trabajo pretende ampliar dicha perspectiva, al presentar también los debates jurídico-institucionales que se llevaron a cabo por los congresos constitucionales anteriores a la pacificación española, así como los desarrollados durante los congresos de Angostura en 1819 y Cúcuta en 1821, sin mirarlos como dos fenómenos separados sino abordándolos como parte del complejo proceso de creación del Estado republicano durante esos años.

\section{Los indultos reales}

El indulto, en sentido estricto, tenía como característica la no aplicación de la pena a uno o varios condenados por sentencia firme, por la gracia del príncipe o de aquel a quien se le hubiese otorgado de manera expresa la atribución para decretar perdones generales en nombre del monarca. En sentido amplio, cada indulto estaba regulado por los preceptos dados por cada cédula o carta de perdón, las que regulaban y limitaban su alcance, esto es: podía ser aplicado a reos no condenados, se reduciría o conmutaría la pena en lugar de exonerar a los delincuentes, se concedería tras una compensación por precio, trabajo o servicio a la Corona, etcétera ${ }^{19}$. De esta manera, el estudio de los indultos debe realizarse de manera casuística, entendiendo que cada uno responde a motivaciones propias de cada momento, incluso aquellos que tradicionalmente se otorgaban "con motivo de nacimiento de Príncipes, u otros motivos de alegría, como victoria o paz, etc.; en estos indultos la regla es la misma Cédula de indulto para saber los delitos y casos que comprehende, y los términos en que se ha de entender" 20 .

En Indias se otorgó la potestad graciosa a los virreyes del Perú y Nueva España, quienes no contaron con las atribuciones de los virreyes hispanos en Europa ${ }^{21}$. Al respecto Juan de Solórzano Pereyra, autor consultado frecuentemente por los magistrados, determinó que, de acuerdo con las cédulas que ordenaban su cargo, los virreyes sólo podrían otorgar perdones

\footnotetext{
${ }_{18}$ Ots Capdequí, José María, Las instituciones del Nuevo Reino de Granada al tiempo de la independencia, Consejo Superior de Investigaciones Científicas, Madrid, 1958, p. 385-386.

${ }^{19}$ Rodríguez Flores, M., El perdón real, Op. Cit., p. 15 y $43-44$.

20 Álvarez Posadilla, Juan, Práctica criminal por principios, o modo y forma de instruir los procesos criminales de las causas de oficio de la justicia contra los abusos introducidos, vol. II, Imprenta de la viuda de Ibarra, Madrid, 1797, p. 493. Todas las citas de fuentes citadas y analizadas mantienen la ortografía y puntuación originales.

${ }^{21}$ Lalinde Abadía, Jesús, "El régimen virreinosenatorial en Indias", Anuario de Historia del Derecho Español, Madrid, vol. XXXVII, 1967, p. 210-213.
} 
en casos de rebelión. Solórzano lo dejó planteado de la siguiente manera: "Teniendo entendido, que no aveis de perdonar delitos, que no fueren de rebelión, ó dependientes dellos. Y que de este poder no aveis de usar, sino fuere en casos de guerra, y alteraciones" 22. A pesar de que una cédula de Felipe III, de 1614, incluida en la Recopilación de Leyes de Indias, daba poder total a los virreyes para perdonar delitos ${ }^{23}$, Solórzano dejaba claro que el conjunto de disposiciones limitaba esta gracia al príncipe:

"Y esta disposicion, y resolucion es muy conforme á las reglas de Derecho, que nos enseñan, que el hazer semejantes perdones, y remissiones de delitos, ó estorvar que no se executen las sentencias en ellos dada, es de los que llamas Regalias, y solamente reservado á los Reyes, y Príncipes absolutos, en señal de su Suprema jurisdicción, de donde en nuestros propios términos concluyen Bosio, Cacherano, Avendaño, y otros, que no los Vicarios del imperio, ni los oidores, ni Consejeros por Supremos que sean las pueden hazer" ${ }^{24}$.

Para inicios del siglo XIX el Consejo de Estado de Castilla consideraba que la atribución virreinal para otorgar indultos era totalmente equivocada, por lo menos así quedó plasmado en la respuesta a una consulta realizada por la Audiencia de Guatemala en 1809, en la que el fiscal de dicho Consejo consideró que, a pesar de las circunstancias, el virrey no podía asumir la soberanía ni mucho menos atribuirse la jurisdicción de mero imperio ${ }^{25}$. Se destaca aquí el uso de la doctrina jurídica por parte del fiscal, quien trae a colación las Partidas y la Nueva Recopilación para sostener la exclusividad de la gracia real; igualmente, menciona a Andrés Cornejo y su Diccionario histórico y forense, donde dice que el indulto "es regalía continua inherente á la Real Corona, y persona, quien goza de esta Suprema autoridad, dispensando solo sus mismas leyes en uso de su soberanía"26. El fiscal cita además la Práctica Universal Forense de Francisco Antonio

${ }^{22}$ Libro V, Capítulo XIII. Solórzano Pereyra, Juan de, Politica Indiana, Henrico y Cornelio Verdussen, Amberes, 1703, p. 455.

${ }^{23}$ El texto de dicha cédula, tal como quedó impresa en la Recopilación (Libro III, Ley XXVII) era: "Concedemos Facultad á los Virreyes del Perú y Nueva España, para que puedan perdonar qualesquier delitos y excessos cometidos en las Provincias de su goviernos, que Nos, conforme á derecho y leyes destos Reynos podriamos perdonar, y dar, y librar los despachos necesarios, para que las Iusticias de todos nuestros Reynos y Señorios no procedan contra los culpados, á la averiguacion y castigo, assi de oficio, como á pedimennto de parte, en quanto á lo criminal, reservando su derecho en lo civil, daño, é interesses de las partes, para que le pidan y sigan como les convenga", Recopilación de las Leyes de los Reinos de las Indias, por Julian de Paredes, Madrid, 1681, p. II-17, http://fondosdigitales.us.es/fondos/libros/752/14/recopilacion-de-leyes-de-los-reynos-de-las-indias/, consultado el 19 de marzo de 2015.

${ }^{24}$ Libro V, Capítulo XIII. Solórzano Pereyra, J., Politica Indiana, Op. Cit., p. 455.

${ }^{25}$ Según la Curia Pbilipica, la facultad de hacer justicia en asuntos criminales se denomina mero imperio en tanto para los civiles es mixto imperio. Dicha atribución es exclusiva del monarca, quien la delega a ciertos magistrados para su buen uso en la justicia y gobierno del reino. Hevia de Bolaños, Juan de, Curia Philipica, edición facsímil del original de 1790, Lex Nova, Valladolid, 1989, fol. 19.

26 Archivo Histórico Nacional de España (AHNE), Estado (Estado), L 57, C 74. Cornejo, Andrés, Diccionario bistórico y forense del Derecho Real de España, Madrid, por D. Joachin Ibarra, 1779, p. 357. 
de Elizondo y las Máximas sobre recursos de fuerza y protección de José de Covarrubias, que corroboraban la potestad exclusiva del rey para perdonar. Consideraba finalmente dicho fiscal que aunque a los virreyes se les haya atribuido la facultad de ser alter nos del rey, tal como quedó plasmado además en la Recopilación, ésta había sido limitada a través del tiempo con diversas cédulas, siendo entonces posible otorgar sólo perdones particulares ${ }^{27}$.

El acto de perdonar implicaba una serie de formalismos que configuraron un entramado de limitaciones al ejercicio del perdón; con esto se buscaba garantizar que la gracia real, producto de la misericordia del monarca, no contradijera la justicia ${ }^{28}$. Dicha regulación se basó en la ley promulgada en Valladolid por Juan II de Castilla, en el año de 1447, ratificada posteriormente en la Nueva Recopilación castellana de 1567, la cual dejó claro que "el perdón, que de ligero se hace, da ocasión á los hombres para hacer mal". Ello hacía necesario que, para otorgar la absolución particular, se debía contar con la carta de perdón "firmada de nuestro nombre, i sellada con nuestro sello, i escrita de mano de Escrivano de nuestra Camara, i firmada de espaldas de dos de nuestro Consejos"29. Los formalismos del indulto general estaban dados por la misma cédula real o bando, en el cual se especificaban las autoridades encargadas de verificar la condición del reo y la posibilidad de ser sujeto de gracia; además, cada cédula comprendía una serie de delitos excluidos del perdón. Por regla general estaban exceptuados del perdón los delitos de lesa majestad, la traición, el homicidio alevoso, entre otros delitos graves ${ }^{30}$.

Un ejemplo de cédula de indulto fue la expedida por Carlos IV el 18 de enero de 1803, con motivo del matrimonio de María Antonia, princesa de Nápoles, hija de Fernando IV de Nápoles y María Carolina de Austria, con Fernando, entonces príncipe de Asturias. En este caso fue un indulto general para los reos por delitos militares. El encabezado de la gracia decía:

"Habiendo resuelto el Rey, en celebridad del matrimonio del Príncipe nuestro Señor con la Serenísima señora Dona María Antonia, Princesa de Nápoles, conceder Indulto general á los presos que se hallaren en las cárceles de Madrid, y demas del Reyno, que fuesen capaces de él en los términos que se concedió quando se verificó el matrimonio de S. M. con la Reyna nuestra Señora; lo participo á V. S. de real órden, á fin de que haciéndolo presente en el Consejo de Guerra, disponga este su cumplimiento por lo respectivo á los dependientes del fuero de Guerra y de Marina" ${ }^{\prime 3}$.

\footnotetext{
27 AHNE, Estado, L 57, C 75-78.

${ }^{28}$ Un interesante estudio sobre la clemencia del príncipe en la doctrina y emblemática castellana fue el realizado por Carneiro, Sarissa, "La clemencia del príncipe: su representación alegórica en emblemas y empresas de España y América colonial", Revista Chilena de Literatura, Santiago, n85, 2013, p. 75-100.

${ }^{29}$ Nueva Recopilación, VIII, 25, 2.

30 Rodríguez Flores, M., El perdón real, Op. Cit., p. 100-114; Levaggi, A., "Las instituciones de clemencia”, Op. Cit., p. 246-247.

31 AGNC, Sección Colonia (SC), Juicios Criminales (Criminales), L 67, E 4, f 286r-286v.
} 
Este indulto general estaba destinado a los reos de jurisdicción militar, esto es, soldados desertores que estuvieran o no procesados militarmente. En este caso tendrían que solicitar el indulto a cualquier tribunal del reino, con la única excepción de que hubiese una parte ofendida: entonces debería preceder una manifestación de perdón para poder aplicar el indulto. Expresamente quedaban excluidos los acusados por delitos graves o que pudieran resultar en perjuicio de un tercero, específicamente los que hubiesen cometido delitos de

"lesa magestad divina o humana, la alevocia, el homicidio del sacerdote, el delito de fabricar moneda falsa, el de ynsendiario, la extracción de cosas prohibidas del Reyno, el de blasfemia, el de sodomía, el hurto, el de cohecho, y baratería, el de falcedad, el de resistencia a la justicia, el desafío, el de mala versación en mi Real Hazienda" ${ }^{\prime 32}$.

La cédula fue recibida en Santa Fe el 9 de febrero de 1804, pero sólo se ejecutó desde el 20 de mayo del mismo año.

El 29 de octubre de 1804 se promulga un nuevo indulto, destinado a los militares desertores que se hallaran presos o que estuvieran libres y se les acusara como tales ${ }^{33}$. En este caso el texto del monarca es el siguiente:

"Compadecido mi paternal corazón de la triste situación á que se ven reducidos los desertores de mi exército, que se hallan prófugos dentro y fuera de mis dominios, sin domicilio ni ocupación alguna en beneficio del estado, y expuestos á los males que son consiguientes á su vagancia; y deseando atraerlos al cumplimiento de sus deberes, he venido en concederles el indulto del referido crimen" ${ }^{34}$.

En este caso, los que quisieran recibir dicha gracia deberían dirigirse a sus jefes militares con el fin de ser perdonados y cumplir con el tiempo de servicio que les faltara, contando desde el momento de su fuga, si es que eran desertores por primera vez; los desertores por segunda vez deberían cumplir seis años de servicio, y los de tercera vez deberían pagar ocho años en las milicias.

En la pesquisa documental se hallaron cuatro solicitudes de 1804 que buscaban acogerse al real indulto, tres por homicidio y una por matrimonio clandestino, todas denegadas por la Real Audiencia. En los tres casos por homicidio los implicados se encontraban prófugos y sus peticiones coincidían en fundamentar que solicitaban se les igualara con los demás "reos ausentes y rebeldes" acogidos por la cédula de indulto ${ }^{35}$. Los tres casos por homicidio incluyen las cartas de perdón de los padres de las víctimas, las cuales compartían la misma fórmula:

32 AGNC, SC, Criminales, L 67, E 4, f. 287r. Sobre las excepciones comunes a las promulgaciones de indulto, véase Rodríguez Flores, M., Elperdón real, Op. Cit., p. 114.

33 AGNC, SC, Milicias y Marina (MM), L 53, E 9, f. 61r.

${ }^{34}$ Colón de Larriátegui, Félix, Ju々gados militares de España y sus Indias, por Ibarra, Madrid, 1817, p. 207.

35 AGNC, SC, Criminales, L 6, E 29, f 534r. 


\begin{abstract}
"Francisca de la Parra, vecina de este Valle de Lenguipa [...] madre legítima de Josef Martín de la Cruz, difunto, y haviendole echo saber el escripto y decreto proveido dixo, que se vaja de el pedimento y querella que contra Juan de la Cruz Camacho ha pedido reo [en el homicidio] cometido en el dicho su hijo Josef Martin, y para que Dios Nuestro Señor le perdone lo havsuelve y perdona una, dos y tres ocasiones y cuantas el Derecho le permita y que no tiene que dedusir ni haora ni en ningun tiempo, y que todo lo dicho lo hase por ser christiana y se estre [sic] proximo y a la firmeza de lo dicho obligo su persona y vienes havidos y por haver y renuncio todas las leyes fueros y derechos que hacer puedan a su fabor, domisilio y vesindad, y la ley general y todas las leyes que hasen a fabor de las mugeres y para que confie, yo dicho alcalde certifico en toda forma de derecho que hasi lo dixo, otorgo y no firmó, y a su rruego lo hizo uno de los testigos[...]"36.
\end{abstract}

A pesar de esto, los fiscales encargados de los casos consideraron que no eran dignos de clemencia puesto que las averiguaciones no evidenciaron que estuvieran excluidos de las excepciones estipuladas en la Real Cédula de indulto, específicamente el homicidio intencional. En el caso del delito de matrimonio clandestino, el fiscal determinó que las indagaciones realizadas por el Teniente de la ciudad de Quibdó eran insuficientes para determinar si este delito se encontraba dentro de los exceptuados por la real gracia o si necesitaba algunos requisitos para su condonación ${ }^{37}$.

Respecto a los indultos concedidos por lo virreyes, existen dos ejemplos paradigmáticos para el caso del Nuevo Reino de Granada: el concedido por el virrey Antonio Caballero y Góngora después de la revolución de los comuneros en agosto de 1782 y el promulgado por Antonio José Amar y Borbón el 14 de octubre de 1808. El primero, realizado por el virrey en nombre de Carlos III, ya fue analizado con cierta profundidad por María Victoria Montoya, quien asume como hipótesis que el indulto fue motivado por tres causas: la imposibilidad de castigar a todos los levantados después de la rebelión comunera, la posibilidad de legitimar al nuevo virrey y permitir el avance de las reformas institucionales de Carlos III ${ }^{38}$. En este indulto queda en evidencia la política de crueldad y clemencia que el alter ego del príncipe cumplía en el Nuevo Reino, por una parte el castigo ejemplar de las cabezas más visibles del movimiento, por otra el indulto y perdón de los presos y de los participantes en el movimiento que aún se encontraban en libertad ${ }^{39}$.

El indulto de Amar y Borbón de 1808 no se promulgó para calmar una rebelión sino para garantizar el orden y contribuir al fortalecimiento de las milicias del reino. El virrey buscaba con este perdón la reincorporación de los desertores a las filas del ejército real, ya fuera

36 AGNC, SC, Criminales, L 148, E 19, f 1004v.

${ }^{37}$ AGNC, SC, Criminales, L 138, E 9, f 611v.

38 Montoya Gómez, "Castigo y perdón”, Op. Cit., p. 45.

${ }^{39}$ Edicto para manifestar al público el indulto general, concedido por nuestro Catholico Monarca el Señor Don Carlos III. A todos los comprehendidos en las revoluciones acaecidas en el año pasado de mil setecientos ochenta y uno, Santafé de Bogotá, 1782. 
mediante la presentación a los jefes militares o la justicia ordinaria, que los ubicaría nuevamente en las filas. Otro grupo de delincuentes que abarcaba este indulto eran los contrabandistas "de toda clase de fraude", siempre y cuando no estuvieran sindicados de robo u homicidio, con la condición de que se incorporaran al "servicio de Armas ó Marinas para defensa del Rey y de la Nación por el tiempo que subsistan las actuales circunstancias". Así mismo, todos los delincuentes que no estuvieran acusados de delitos que merecieran pena corporal serían incluidos en el perdón, aunque para conservar "la mayor equidad posible", se estimaría si ello podría ser útil a la Patria ${ }^{40}$.

A diferencia de Caballero y Góngora, el virrey utilizó la potestad otorgada por las leyes de indias para promulgar el indulto, expresamente diría que lo hizo

"en uso de las facultades de la ley veinte y siete del titulo y libro tercero de las municipales que me esta conferida tambien por Real despacho expedido al mismo tiempo con los demas con que fui embiado y elegido para el mando de este Reyno por la magestad del Señor Don Carlos quarto".

El virrey Amar y Borbón dejó expreso en su perdón que lo hacía “a exemplo é imitacion” del monarca, y añadía que

"en ninguna otra ocacion mejor que la presente debera de resplandecer entre todos los subditos de mi dependencia la mas acrisolada lealtad, y ternura al propio nuevo soberano, y una adhecion qual conviene á las medidas y suprema que han influido los enunciados acaecimientos de la metropoli pudiera hacerse en uso general y trascendente"

Sólo unos días después de promulgado el indulto por el virrey, 22 presos rematados de Cundinamarca solicitaron, colectivamente, ser acogidos en el perdón, propuesta que fue rechazada por la Audiencia de Santafé ya que cada preso debía presentar su solicitud por separado $^{42}$. En los días y meses siguientes el asesor de la Real Audiencia leyó las solicitudes y fue rechazando una tras otra, ya fuera porque estaba por fuera de las causales de indulto ${ }^{43}$, porque se requería mayor información ${ }^{44}$ o porque no incluían la carta de perdón de la parte afectada ${ }^{45}$. La idea de un rechazo general de las solicitudes de indulto no implica que se haya negado la totalidad de ellas; además de la inevitable pérdida de documentación, muchos casos se llevaron en instancias locales donde se solicitaba a los alcaldes ordinarios

40 AGNC, SC, Criminales, L 2, E 14, f. 760v-761r.

${ }^{41}$ AGNC, SC, Criminales, L 2, E 14, f. 760r

42 AGNC, SC, Criminales, L 90, E 33.

43 AGNC, SC, Miscelánea (Miscelánea), L 122, E 6.

44 AGNC, SC, Criminales, L 145, E 22. AGNC, SC, Criminales, L 139, E 9. AGNC, SC, Criminales, L 78, E 10. AGNC, SC, Criminales, L 76, E 26. AGNC, SC, Criminales, L 50, E 2. AGNC, SC, Criminales, L 70, E 8.

${ }^{45}$ AGNC, SC, Criminales, L 10, E 2. 
la ampliación de información. Por lo tanto, una revisión posterior de los archivos regionales puede dar mayores luces sobre el verdadero impacto del indulto de Amar y Borbón en el Nuevo Reino de Granada.

\section{El indulto en las primeras constituciones}

Después de las abdicaciones de Bayona de 1808, el Nuevo Reino de Granada entró en un proceso reorganización política que resultaría en la confederación de una docena de entidades provinciales, representadas por igual número de juntas provinciales. Este proceso fue especialmente fuerte desde 1810, ya que las juntas comenzaron a promover modelos políticos liberales que en buena medida quedarían plasmados en las constituciones provinciales que se promulgaron entre 1810 y 1815. De esta manera, no es sorpresivo que fuese en la "periferia" del virreinato donde se produjeron las primeras promulgaciones de independencia y así mismo, fueran ésos los lugares de mayor conflicto entre las tropas realistas e insurgentes en la guerra independentista posterior ${ }^{46}$. En este contexto de fragmentación política fueron discutidas las implicaciones del indulto, lo cual conllevó a debatir cuál de los tres poderes tendría la potestad para declarar el perdón a los delincuentes.

La segunda mitad del siglo XVIII fue el escenario para cuestionar el sistema jurídico hispánico, tanto por alegatos de obsolescencia como de crueldad de la justicia castellana. Fue común entre los constitucionalistas la consideración de que el arbitrismo judicial permitía el abuso de los jueces, y por ende la injusticia, no sólo por una aplicación desmedida de la pena, sino también por perdonar a los delincuentes, perjudicando con ello a las víctimas. Un trabajo que tuvo amplia difusión en la península, en especial después de la invasión francesa, fue el tratado de Práctica criminal escrito por el granadino Joseph Marcos Gutiérrez ${ }^{47}$. Este autor, basándose en tratadistas como Gaetano Filangieri ${ }^{48}$, catalogó la práctica del indulto real como una injusticia hecha a la sociedad. Al igual que Solórzano, consideraba que la clemencia era una atribución regia fundada en la "dulzura"

\footnotetext{
${ }^{46}$ El ejemplo paradigmático de desplazamiento del eje político "del centro hacia la circunferencia" fue el mostrado por Antonio Annino para el caso novohispano, después de la implementación de la constitución de Cádiz. Annino von Dusek, Antonio, "Voto, tierra, soberanía: Cádiz y los orígenes del municipalismo mexicano", en Guerra, François-Xavier (ed.), Revoluciones hispánicas : independencias americanas y liberalismo español, Universidad Complutense, Madrid, 1995, p. 270; véase también Gutiérrez Ardila, D., Un nuevo reino, Op. Cit., p. 229-233.

47 Ortego Gil, Pedro, Entre jueces y reos. Las postrimerías del Derecho penal absolutista, Dykinson, Madrid, 2015, p. 28.

${ }^{48}$ Sobre la recepción de Gaetano Filangieri en la Nueva Granada, específicamente en el proyecto de construcción del código penal de 1837, véase Escobar Villegas, Juan Camilo \& Adolfo León Maya Salazar, "Ilustrados, leyes penales, control social y administración de justicia durante la época de las revoluciones modernas en nueva Granada: una mirada desde la obra de Gaetano Filangieri”, Revista Historia de la Educación Latinoamericana, Tunja, $\mathrm{n}^{\circ}$ 9, 2007, p. 141-180. Respecto a la difusión de la obra de Filangieri en el mundo atlántico, véase Morelli, Federica, "Tras las huellas perdidas de Filangieri: nuevas perspectivas sobre la cultura política constitucional en el Atlántico hispánico", Historia contemporánea, Bizkaia, n³3, 2006, p. 431-462.
} 
del soberano como una manera de reparar el rigor de algunos jueces, pero sería una "legislación criminal defectuosa" la que habría permitido el abuso de los magistrados y, por ende, la necesidad de la recuperación de la equidad por parte del monarca. En este sentido, como contraposición, una legislación que limitara los abusos de los jueces haría innecesario el uso del recurso de clemencia regia y, en consecuencia, evitaría la injusticia social ${ }^{49}$.

En concordancia con lo planteado por Joseph Marcos Gutiérrez, sin que esto implique una lectura directa de su tratado, algunos constituyentes neogranadinos tratarían posteriormente el poder de otorgar indultos basados en la necesidad de imponer la legislación a la voluntad del soberano o presidente. Es posible que los constituyentes tomaran el Tratado de los delitos y de las penas, en la traducción de Juan Antonio de las Casas, quien habría planteado la supremacía de la ley, incluso en el perdón real, de la siguiente manera:

"Pero considérese que la clemencia es virtud del Legislador, no del executor de las Leyes: que debe resplandecer en el Códice, no en los juicios particulares: que hace ver á los hombres la posibilidad de perdonar los delitos, y que la pena no es necesaria conseqüencia suya; es fomentar el alhago de la impunidad, y manifestar, que pudiéndose perdonar, las sentencias no perdonadas son mas bien violencias a la fuerza, que providencias de la justicia. ¿Qué deberemos pensar quando el Príncipe concede perdón, esto es, la seguridad pública, á un particular, y que con un acto privado de mal entendida beneficencia, forma un decreto público de impunidad? Sea, pues, inexôrables las Leyes, é inexôrables sus executores en los casos particulares; pero sea suave, indulgente y humano el Legislador" ${ }^{\prime 50}$.

\subsection{Los indultos según los constituyentes de Cundinamarca}

El esfuerzo de ser indulgente recaía sobre el legislador; sin embargo, los constituyentes de Cundinamarca en 1811 determinaron que sería el Poder Ejecutivo quien tendría la "preciosa facultad" de conceder indultos generales "del modo y en los casos que hasta ahora se ha practicado" 51 . Un artículo, que en la imprenta quedó reducido a dos líneas, fue objeto de un intenso debate antes de redactarse de manera definitiva. En la propuesta original se determinaba que el presidente "de acuerdo con los Consejeros" tendría la facultad de conceder indultos; dicha autoridad estaría fundamentada en el hecho de que los constituyentes determinaron que la presidencia tendría las funciones de virrey, entendido como "Vice-

\footnotetext{
${ }^{49}$ Gutiérrez, José Marcos, Práctica criminal de España, en la Oficina de Don Benito García y Compañía, Madrid, 1804, parte I, p. 329-331.

${ }^{50}$ Beccaria, Cesare, Tratado de los delitos y de las penas, por D. Joachín Ibarra, Madrid, 1774, p. 251-253.

51 "Artículo 35: El Poder Ejecutivo tiene la preciosa facultad de conceder indultos generales, del modo y en los casos que hasta ahora se ha practicado", Constitución de Cundinamarca: su capital Santafé de Bogotá, Imprenta patriótica de don Nicolás Calvo y Quixano, Bogotá, 1811.
} 
gerente" del Monarca pero con los mismos honores que tenía la figura virreinal ${ }^{52}$. En este sentido, el presidente sólo podría hacer uso del perdón en los mismos casos que Solórzano Pereira había determinado, tal como lo dejó expreso el constituyente por el partido de Zipaquirá, Domingo Camacho Quezada, quien asimismo consideraba que este arbitrismo era inconveniente y así lo habría demostrado la misma ley castellana.

El problema que plantearon algunos constituyentes era que, si bien estaban de acuerdo con la supremacía de la ley sobre el arbitrio judicial, no había posibilidad de resolver, en un corto plazo, la creación de un código criminal; por lo tanto, las leyes castellanas, consideradas severas y bárbaras, tendrían un rigor mayor al no contar con la clemencia del juez. Jorge Tadeo Lozano consideraba que más valía pecar por clemencia que por severidad, y apoyaba el permitir al presidente otorgar indultos particulares. Otro eminente abogado de la audiencia, Camilo Torres, defendía el sentido de la clemencia del juez; pero ante todo, argumentaba que el procedimiento judicial -que permitía al reo la apelación casi interminable de su causa-, evitaba que las penas más rigurosas fueran aplicadas, con la excepción de aquellos casos en que "el delito era tan horroroso y atroz, que no dexaba el menor lugar á la exculpación".

Sin embargo, en manos del ejecutivo la clemencia podría ser perjudicial. En primer lugar porque el presidente se convertiría en el tribunal de apelación al cual recurrirían todos los culpables por delitos graves, "por que ¿qual seria el reo que omitiría este paso quando se trataba de salvar la vida; y quien seria el que no podría alegar algunos sevicios ya suyos, ya de sus mayores?"; en segundo lugar, porque implicaría subordinar el poder judicial al ejecutivo, perdiendo el primero su independencia; finalmente, el poder ejecutivo estaría sometido a una alta cantidad de procesos, implicando así una sobrecarga para los encargados de éste ${ }^{53}$.

Es evidente que Torres era un defensor de la clemencia de los jueces, pero quería evitar que el ejecutivo detentara dicha potestad, en especial porque éste sería el único que podría perdonar los delitos condenados con pena corporal ${ }^{54}$. La opinión que prevaleció entre los colegiados fue que, aunque debía existir la posibilidad de que el presidente pudiera otorgar indultos generales, el espíritu general entre los jueces y el ejecutivo debería ser de garantizar la igualdad de los ciudadanos ante la ley, garantizar la aplicación rigurosa de la ley, y sobre todo, corregir la "benignidad y aún indulgencia" con la cual, afirmaban, se trataba a los delincuentes en los tribunales ${ }^{55}$.

\footnotetext{
52 "Título 5, Artículo 9", Constitución de Cundinamarca de 1811. Actas del serenísimo colegio Constituyente y electoral de la Provincia de Cundinamarca: congregado en su capital la ciudad de Santafé de Bogotá para formar y establecer su constitución, Imprenta Real de Santafé de Bogotá, Bogotá, 1811, p. 57.

53 Actas del serenísimo colegio Constituyente y electoral de la Provincia de Cundinamarca, p. 48-50.

54 Actas del serenísimo colegio Constituyente y electoral de la Provincia de Cundinamarca, p. 51-52.

55 Actas del serenísimo colegio Constituyente y electoral de la Provincia de Cundinamarca, p. 55-56.
} 
La facultad de conceder indultos sería utilizada por Antonio Nariño, presidente del Estado de Cundinamarca, el 24 de diciembre de 1811. Fue un indulto general concedido a todos los presos y arrestados del Estado, con la excepción de aquellos que hubiesen cometido "acciones civiles del fisco o tercero", traición, malversación del tesoro público, "resistencia formal con armas a la justicia", homicidio alevoso o en sacerdote, sodomía, bestialidad y "todos los que legalmente se califiquen de atroces" 56 .

La reforma de la constitución de Cundinamarca, publicada en 1812, cuya modificación más importante fue la de declarar a la provincia como una república representativa independiente de España, limitó más aun la capacidad del poder ejecutivo para decretar indultos generales: "El Poder Executivo tiene la preciosa facultad de conceder indultos generales, pero solo en los casos de guerra, y crímenes de conmociones populares" 57 . La preciosa facultad fue utilizada nuevamente por Antonio Nariño en septiembre de 1812, cuando decretó:

"Se concede indulto a todo soldado, cabo y sargento que hasta el día se haya desertado o servido contra el Estado, si en el término de un mes se presentare y jurare el gobierno; pero a todo soldado, cabo o sargento que de hoy en adelante cometiere cualquiera de estas faltas, será irremediablemente castigado con la pena que la ordenanza le impone" ${ }^{35}$.

La gracia de conceder perdones será retirada definitivamente con la modificación constitucional de 1815 , pero serán entonces los generales de los ejércitos quienes decreten los diferentes perdones generales.

\subsection{Los indultos según los constituyentes de Antioquia}

"Son varios los casos que presentan nuestros códigos en que la virtud de la clemencia debe referirse al rigor que ellos prescriben y sería mucha lástima poner de antemano una traba a nuestro Supremo Gobierno que, sobre impedirle el obrar lo mejor en ciertas circunstancias, lo despoja del atributo más grandioso con que puede parecer delante de sus Pueblos. Concluyo, Señor, diciendo que se puedan conceder indultos generales cuando lo permita el bien del Estado" ${ }^{39}$.

\footnotetext{
${ }^{56}$ Documento 24. Hernández de Alba, Guillermo (ed.), Archivo Nariño, Biblioteca de la Presidencia de la República, Santafé de Bogotá, 1990.

57 Título V, Artículo 28. Constitución de la República de Cundinamarca reformada por el Serenísimo Colegio Revisor y Electoral, Imprenta de Don Bruno Espinosa, Santafé de Bogotá, 1812, p. 28-29.

${ }^{58}$ Documento 88. Hernández de Alba, G., Archivo Nariño, Op. Cit.

59 "Actas del Colegio Electoral y Constituyente de Antioquia", Gutiérrez Ardila, Daniel (ed.), Actas de los colegios electorales y constituyentes de Cundinamarca y Antioquia, 1811-1812, vol. II, Colección Bicentenario 7, Universidad Externado de Colombia / Universidad Industrial de Santander, Bogotá / Bucaramanga, 2010, p. 113.
} 
Una tercera posición, planteada por el legislador Andrés Avelino de Uruburu, consideraba que el perdón debía ser una facultad del ejecutivo ante la rigurosidad de las leyes vigentes, pero cuidando que no se indultara la traición a la Patria, de la misma manera que el monarca no otorgaba su gracia a los delincuentes por lesa majestad ${ }^{60}$. Finalmente, la discusión quedaría saldada a favor de la segunda posición y quedó plasmada en el artículo 35 del título IV de la Constitución de Antioquia, que rezaba: "Reside en el Presidente la preciosa facultad de conceder indultos generales, cuando lo permita el bien del Estado" ${ }^{61}$. Dicha atribución fue trasladada posteriormente al Gobernador provincial, cuando Antioquia pasó a formar parte de las Provincias Unidas de la Nueva Granada, y así quedaría expresado en el artículo 29 del título IV de la Constitución Provisional ${ }^{62}$.

\subsection{Los indultos en las constituciones provinciales de 1814 a 1815}

Con excepción de la constitución de Popayán de 1814, las demás provincias no dejaron plasmada en su constitución la posibilidad de que algún poder del Estado pudiera proclamar indultos. En el caso de la carta payanesa, ello quedó expreso en el numeral cuatro del artículo 77, que detalló las funciones del poder ejecutivo en la provincia: el gobernador podría "perdonar o mitigar la pena, aunque sea capital, pero con consulta y dictamen favorable del Tribunal de Justicia"63. En todo caso, las constituciones provinciales de Cartagena (1812) Neiva y Mariquita (1815) dejaron claro el hecho de que ningún juez tendría el arbitrio para perdonar delitos o suspender las causas judiciales ${ }^{64}$, en tanto las de Tunja (1812) y Pamplona (1815) no mencionan la posibilidad de otorgar perdones.

\section{Indultos y guerra}

Para 1811 la guerra estaba declarada, no sólo contra España, sino dentro del mismo Reino de Nueva Granada, que se encontraba dividido en una docena de entidades soberanas y múltiples facciones armadas, las que vieron en la crisis monárquica la posibilidad de fortalecer su autonomía respecto al gobierno de Santafé65. Al año siguiente las acciones militares

\footnotetext{
60 "Actas del Colegio Electoral y Constituyente de Antioquia", p. 112.

${ }^{61}$ Constitución del Estado de Antioquia sancionada por los representantes de toda la Provincia y aceptada por el pueblo el tres de mayo del año de 1812, Imprenta de Don Bruno Espinosa, Santafé de Bogotá, 1812, p. 47-48.

${ }^{62}$ Constitución provisional de Antioquia, revisada en convención de 1815, Imprenta del Gobierno, Medellín, 1815, p. 27.

63 "Proyecto de constitución de la Provincia de Popayán, formado por el serenísimo colegio electoral y constituyente del presente año de 1814", Boletín Histórico del Valle, Cali, nº49-53, 1938, p. 44.

${ }^{64}$ Sección IV, Artículo 25, Constitución política del Estado de Cartagena de Indias, Imprenta del ciudadano Diego Espinosa, Cartagena, 1812, p. 95; Sección cuarta, Artículo 24, Constitución del Estado libre de Neiva revisada en el año de 1815, Imprenta San Bernardo, Bogotá, 1914, p. 32; Título 17, Artículo 17 Constitución de Mariquita, Imprenta del Estado, Santafé de Bogotá, 1815, p. 30.

${ }^{65} \mathrm{El}$ estado de conflicto que se presentó después de los congresos constitucionales hasta la pacificación en 1816 es analizado por Reyes Cárdenas, Ana Catalina, "El derrumbe de la primera república en la Nueva Granada entre 1810 y 1816”, Historia Crítica, Bogotá, n²41, 2010, p. 38-61.
} 
encabezadas por tropas realistas e insurgentes, así como entre las diferentes facciones al interior de las provincias neogranadinas, se multiplicaron por diversas regiones del virreinato. La guerra se sostiene durante casi una década, hasta que finalmente se obtiene la victoria definitiva de los patriotas en Carabobo el 24 de junio de 1821. En este contexto, las incursiones armadas se acompañan de compasión, al menos así se hace aparecer en las proclamas de indulto. Aunque todo parece indicar que fue menos la clemencia, que la táctica, la que impulsó la combinación de armas y perdones durante la guerra de independencia colombiana. La Tabla 1 presenta un listado parcial de los indultos generales que se promulgaron entre 1808 y 1821, ofrecidos por diversas autoridades y con diferente ámbito de aplicación, pero en la mayoría de los casos otorgados para obtener como rédito una ventaja militar.

Un aspecto importante dentro de los enfrentamientos lo ocupa la proclama de "guerra a muerte", dada por Simón Bolívar en junio de 1813, en la cual el conflicto adquiere su matiz más radical cuando el ejército bolivariano suspende el derecho de gentes, sustentado en la "disolución" de la república, gesto que autorizaría al gobierno "para obrar según las circunstancias, sin ceñirse a la letra de las leyes y constituciones" 66 . Sin embargo, es evidente que el impacto que pudo generar un decreto de guerra contra "los españoles", también debía estar acompañado de una declaración de clemencia. Después de la victoria de Araure, el 5 de diciembre de 1813, Bolívar decide, como un acto de indulgencia ante los americanos que batallaron en el ejército realista, proclamar un indulto general para estos soldados durante un mes, contado desde la publicación del decreto en cada pueblo ${ }^{67}$. El 28 de enero de 1814 se amplía no sólo el tiempo de vigencia del indulto (ahora sería por tiempo ilimitado), además se incluyen en éste los españoles, canarios y desertores de las tropas republicanas que se entregaran con sus armas, o sin ellas, a los jefes militares o magistrados republicanos ${ }^{68}$.

Los perdones de Bolívar avanzaron junto a su tropa. Por ejemplo, en 1816, en una comunicación a los habitantes de Caracas, dijo: "Vuestros tiranos serán destruidos ó expelidos del país, y vosotros restituidos á vuestros derechos, á vuestra patria y á la paz. La guerra a muerte que nos han hecho nuestros enemigos cesará por nuestra parte: perdonaremos á los que se rindan, aunque sean españoles"69. En el mismo tenor, otros generales republicanos tomarían el modelo de Bolívar y otorgarían indultos para territorios específicos, como hizo el general García de la Sena, quien publicó un indulto para los soldados del ejército realista en el ámbito de las aldeas llaneras desde Barinas hasta Bellotes ${ }^{70}$.

\footnotetext{
${ }^{66}$ Citado en Thibaud, Clément, Repúblicas en armas, Op. Cit., p. 128.

${ }^{67}$ Bolívar, Simón, Proclamas de Simón Bolivar libertador de Colombia, D. Appleton y compañía, Nueva York, 1853 , p. 17-18.

68 Bolívar, Simón, Escritos del libertador, vol. VI, Sociedad Bolivariana de Venezuela, Caracas, 1969 , p. 64.

${ }^{69}$ Bolívar, S., Proclamas, Op. Cit., p. 20.

70 Thibaud, C., Repúblicas en armas, Op. Cit., p. 179.
} 
Revista Historia y Justicia

ISSN 0719-4153 revista.historiayjusticia.org

N6 - Santiago de Chile, abril 2016, p. 228-257

Tabla 1. Listado parcial de indultos promulgados entre 1808 y 1821

\begin{tabular}{|c|c|c|c|}
\hline Año & Otorga & Destinatarios & Ámbito \\
\hline 1808 & Virrey Amar y Borbón & Delincuentes & Nuevo Reino de Granada \\
\hline 1811 & Presidente Antonio Nariño & Delincuentes & Estado de Cundinamarca \\
\hline 1812 & Presidente Antonio Nariño & Desertores & Estado de Cundinamarca \\
\hline 1813 & General Bolívar & Americanos en el ejército realista & Venezuela \\
\hline 1814 & General Bolívar & Soldados realistas & $\begin{array}{l}\text { Venezuela y Nueva } \\
\text { Granada }\end{array}$ \\
\hline 1814 & Fernando VII & Militares desertores & Reino \\
\hline 1814 & Fernando VII & Delincuentes & Madrid y el reino \\
\hline 1816 & General Bolívar & Soldados rendidos & $\begin{array}{l}\text { Venezuela y Nueva } \\
\text { Granada }\end{array}$ \\
\hline 1816 & Fernando VII & Delincuentes & Reino \\
\hline 1816 & General Morillo & Insurgentes & Nuevo Reino de Granada \\
\hline 1816 & General Morillo & Oficiales rebeldes & Nuevo Reino de Granada \\
\hline 1816 & $\begin{array}{l}\text { Virrey Francisco Montalvo y } \\
\text { Ambulodi }\end{array}$ & Insurgentes & Cartagena \\
\hline 1817 & General Morillo & Insurgentes & Venezuela y Nuevo Reino \\
\hline 1819 & Congreso General de Venezuela & $\begin{array}{l}\text { Desertores, soldados realistas y } \\
\text { delincuentes }\end{array}$ & Venezuela \\
\hline 1819 & Fernando VII & Desertores y delincuentes & Reino \\
\hline 1820 & Congreso General de Venezuela & $\begin{array}{l}\text { Desertores, soldados realistas y } \\
\text { delincuentes }\end{array}$ & $\begin{array}{l}\text { Venezuela y Nueva } \\
\text { Granada }\end{array}$ \\
\hline 1821 & Congreso General de Colombia & Delincuentes & Colombia \\
\hline
\end{tabular}

Fuentes: AGNC, SC, Criminales, L 2, E 14, 759-766. Documentos 24 y 88 en Hernández de Alba, G., Archivo Nariño, Op. Cit. Bolívar, Simón, Proclamas de Simón Bolívar, Appleton y compañía, Nueva York, 1853, p. 17-18. Bolívar, Simón, Escritos del Libertador, Sociedad Bolivariana de Venezuela, Caracas, p. 64. Gaceta de Madrid, n¹25, 13 de septiembre de 1814, p. 1030-1034. Gaceta de Madrid, $\mathrm{n}^{\circ} 140,18$ de octubre de 1814, p. 2059-2060. Cuño Bonito, Justo, El retorno del rey, Universitat Jaume I, Castelló de la Plana, 2013, p. 88 y 223. Real Academia de la Historia, Signatura 9/7654, Legajo 11, f 94. Biblioteca Nacional de Colombia, Fondo Quijano, volumen 253, pieza 30. Mercado, Jorge, Campaña de invasión del Teniente General don Pablo Morillo, Ediciones LAVP, Bogotá, 2015, p. 54. Real Academia de Historia, Signatura 9/7650, Legajo 7, f 175. Archivo Histórico Provincial de Zaragoza, Real Audiencia de Aragón, E 1002, Documento 4. Cuerpo de leyes de la república de Colombia que comprende todas las leyes, decretos y resoluciones dictados por sus congresos desde el de 1821 hasta el último de 1827, Imprenta de Valentín Espinal, Caracas, 1840, p. 24-25. Actas 6 y 10 del Congreso de Angostura, en Cortázar, Roberto y Luis Augusto Cuervo, eds. Actas del Congreso de Angostura 1819-1820, Biblioteca de la Presidencia de la República, Bogotá, 1988, http://www.bdigital.unal.edu.co/7847/. Acta 21 del Congreso de Cúcuta en Actas del Congreso de Cúcuta 1821, Biblioteca de la Presidencia de la República, Bogotá, 1989. 
De los expedientes consultados, sólo uno de ellos solicita el indulto que ofreció Bolívar. La solicitud fue realizada por el fraile Pedro Corella, religioso capuchino y cura doctrinero de indios motilones, fundador del pueblo de San José de las Palmas en la jurisdicción de Maracaibo, hoy Norte de Santander. La petición fue realizada en octubre de 1814 al Poder Ejecutivo de la República arguyendo que

"la constitución de esta República ordena y manda, que a ningun Reo se le castigue sin primero ser oydo. En segundo lugar á todo reo se le debe confesionar a los tres días y cumplo quinientos y trece días sin haberme confesionado ni en Cucuta, ni en Pamplona, ni menos en Tunja después de estar aquí catorce meses y veinte y quatro días" ${ }^{71}$.

Paradójicamente, aquella constitución que se oponía a "la práctica opresiva de no oír la voz de los litigantes" 72 era la que no le había concedido la oportunidad de defenderse. El fraile se quejaba de que otros presos ya habían obtenido su libertad gracias al indulto que el general Bolívar había otorgado para dar la libertad a todo español que se hallase preso, y diría: "soy yo uno de ellos por haber nacido en la Peninsula, y si no se me con[ce]de mi libertad y pasaporte por Chapeton, concedaceme por ser Americano, que entré á tierra Americana el dia 23 de diciembre de 1783, que asi en justicia mediante ella"73. El sacerdote sería conducido con las tropas hacia Ocaña, donde el alcalde ordinario debería interrogarlo; no conocemos otro documento que permita saber cuál fue el destino del religioso.

El desorden administrativo del momento es evidente, los mismos jueces y autoridades encargadas de gestionar las solicitudes de indulto no conocen con precisión la manera de llevar las causas. Según las determinaciones del Poder Ejecutivo, se debía conformar una Comisión de Indulto que valorara las solicitudes, según el bando de indulto - del cual no se encontró copia. Las apelaciones de indulto debían ser elevadas por el alcalde ordinario, que cumplía las funciones judiciales que estaban estipuladas en la Novísima Recopilación, es decir las funciones de "jueces naturales de primera instancia para el fuero común" 74 . Sin embargo, uno de los procuradores de pobres de Santa Fe se quejaba de que los alcaldes dilataban el envío de la apelación, con el fin de cumplir con los tiempos requeridos para poder condenar a los sindicados ${ }^{75}$.

La llegada de Fernando VII al trono fue acompañada de una serie de indultos que buscaban, según palabras del monarca, dispensar las gracias y alivios que permitieran la equidad y la justicia, como muestra de su paternal amor a sus vasallos. El primero se

\footnotetext{
${ }^{71}$ AGNC, SC, Miscelánea, L 68, E 34, f. 625r.

${ }_{72}$ Título VII, Artículo 34, Constitución de Cundinamarca de 1811, p. 28.

73 AGNC, SC, Miscelánea, L 68, E 34, f. 625.

${ }^{74}$ Agüero, A., Castigar y perdonar, Op. Cit, p. 68.

75 AGNC, SR, Criminales, L 75, E 53, ff 431r-431v.
} 
decretaría el 2 de septiembre de 1814 y estuvo dirigido a los militares desertores, presos o prófugos, como resultado de las "insinuaciones" de la Junta de Generales y el Infante Don Carlos María Isidro de Borbón, hermano del rey ${ }^{76}$. Posteriormente ese mismo año, con motivo de su primer cumpleaños después de regresar al trono, se concedió indulto general a todos los presos de las cárceles de Madrid y del reino, excluyendo los crímenes de lesa majestad divina o humana, alevosía, homicidio de sacerdote, extracción de cosas prohibidas del reino, blasfemia, sodomía, hurto, cohecho, baratería, falsedad, resistencia a la justicia y malversación de la Real Hacienda ${ }^{77}$.

La opinión política de los republicanos tendería desde entonces a rechazar los indultos, entendidos como una herramienta política a favor de la Corona. En el Argos de la Nueva Granada se publicarían unas notas tituladas "Comentarios al Decreto de Fernando $7^{\circ}$ de España dado en Valencia a 4 de Mayo de 814", posiblemente escritas por el entonces agente de la Nueva Granada en Londres José María del Real, en las cuáles, ante la frase del monarca que decía "Yo os juro y prometo a vosotros, leales Españoles", respondería el comentarista: "Juramentos y promesas, indultos y perdones que ultrajan la dignidad del hombre, son ordinariamente los primeros medios que emplean los tiranos para persuadir a los pueblos a que vuelvan mansamente a la esclavitud"78.

En los primeros meses de 1815 las huestes del conde de Cartagena, el mariscal Pablo Morillo, arriban a las costas neogranadinas, iniciando una rápida y efectiva campaña de pacificación del Nuevo Reino. Después de la difícil y costosa toma de Cartagena por las tropas realistas, se desató una política de terror por parte de Morillo y el brigadier Pascual Enrile, que dejaría cientos de ejecutados. Mas, cuando partieron hacia Santa Fe y dejaron al mando al virrey Francisco Montalvo, éste publicó un indulto general el 9 de abril de 1816, que dejaría en libertad a la mayoría de los presos $^{79}$. Tal decisión crearía sospecha en Enrile, quien escribió a Morillo indicándole que gracias a dicho indulto Cartagena se había inundado de "malvados que se habían refugiado en las yslas extranjeras, y traen consigo además del

\footnotetext{
${ }^{76}$ Gaceta de Madrid, nº 125, 13 de septiembre de 1814, p. 1030-1034.

77 Gaceta de Madrid, n¹40, 18 de octubre de 1814, p. 2059-2060. Aunque las cédulas podían modificar los delitos excluidos de gracia, la mayoría de indultos del siglo XVII y XVIII repetía la fórmula que exceptuaba los delitos considerados más graves, entre ellos el homicidio intencional o alevoso. Rodríguez Flores, M., El perdón real, Op. Cit., p. 114.

78 "Comentarios publicados en El Argos de la Nueva Granada respecto al decreto de Fernando $7^{\circ}$ reasumiendo el trono", en Vanegas, Isidro (ed.), Plenitud y disolución del poder monárquico en la Nueva Granada. Documentos 1807-1819, Universidad Industrial de Santander, Bucaramanga, 2010, p. II, p. 235.

79 Cuño Bonito, Justo, El retorno del rey el restablecimiento del régimen colonial en Cartagena de Indias (1815-1821), Universitat Jaume I, Castelló de la Plana, 2013, p. 88.
} 
perverso modo de pensar que llevaron las ideas que han adquirido en aquellas posesiones todas dispuestas para subvertir el orden en estos países" $\$ 0$.

En 1816 Fernando VII decreta un indulto con motivo del matrimonio de su hermano Don Carlos con la infanta doña María Francisca de Portugal. Manifestaba que lo hacía porque no podría gozar completamente de la felicidad resultante de dicha unión "sin aliviar antes, en quanto permitan las leyes y la situación del Reyno, la suerte de los desgraciados que gimen baxo el peso de sus crímenes", sin que por otorgar dicho perdón se afectaran a terceros o impulsara la venganza pública. La Real Cédula del Supremo Consejo de Indias fue expedida el 29 de septiembre de $1816^{81}$, y recibida en la Real Audiencia de Santa Fe por los oidores Juan Jurado Laynez y Francisco Cabrera el 30 de junio de 181782.

Desde su salida de España, el general en jefe de la hueste realista llevaba consigo la potestad de promulgar indultos generales en nombre del Rey. Sin dicha atribución Morillo no hubiese podido promulgar indultos tan ávidamente: hubiera recurrido a un delito de lesa majestad por atribuirse la jurisdicción de mero y mixto imperio. La atribución fue dada por el Ministerio universal de Indias el 28 de noviembre de 1814, y al ser documento "muy reservado" permitió dejar plasmadas instrucciones que no podía conocer el enemigo:

"En este indulto serán comprendidas aun las personas que en la actualidad están en islas extranjeras, pero no se les nombrará, y sólo en el caso de preguntarlo se les asegurará que sí; pero por el buen orden, tranquilidad general y particular, tendrán que mantenerse en España, por ahora, en donde gusten y en la corte con el beneplácito de S.M., si le concediese. En este número están el marqués del Toro, actualmente en Trinidad, y D. N. León que se mantiene en Caracas, personas nada conveniente en que allí se mantenga" ${ }^{183}$.

Es evidente que los indultos buscaban recolectar afectos, pero también está la intención de conseguir eliminar cabezas de las tropas revolucionarias, ya fuera logrando que se acogieran al indulto general o consiguiendo la delación por parte de algunos indultados. Por esta razón es que la atribución de indulto dada a Morillo pedía que éste la acompañara con recompensas para aquellos "que por notoriedad hayan servido bien, o que a pesar de las apariencias lo justifiquen”, y que pusiera precio "a las cabezas de aquellos que más influencia tengan" 84 .

El 21 de septiembre de 1817 tanto Morillo como el brigadier Juan Bautista Pardo, encargados de la pacificación de las provincias de Venezuela, comunicaron la gracia del

\footnotetext{
${ }^{80}$ Real Academia de la Historia (RAH), Signatura (Sig) 9/7654, Legajo (L) 11, f 94.

${ }^{81}$ Gaceta de Madrid, n³0, 11 de marzo de 1817, p. 277-278.

82 Biblioteca Nacional de Colombia (BNC), Fondo Quijano (FQ), Volumen (V) 253, Pieza (P) 30.

83 Documento reproducido en Mercado, Jorge, Campaña de Invasión del Teniente General don Pablo Morillo 1815-1816: El régimen del terror, Ediciones LAVP, Bogotá, 2015, p. 54.

${ }^{84}$ Mercado, J., Campaña de Invasión, Op. Cit., p. 54.
} 
indulto real. El mariscal Morillo presentó una proclama a los pueblos de Venezuela, en la cual les comunicaba el indulto real:

"Un indulto para todos los comprendidos en las pasadas y presentes insurrecciones, procesados, ó no procesados, ausentes y existentes, un olvido general, el término de las desgracias que han alejado la tranquilidad de vuestro suelo, es el que en nombre del más amado, y más clemente de los Soberanos, se publica en esta fecha" ${ }^{\$ 5}$.

El mariscal continúa su proclama instando a los venezolanos a deponer las armas, abrazar el indulto y volver a sus casas, poniendo como ejemplo a Nueva España: "Los habitantes de la Nueva España se han apresurado á acogerse á él: aquellos que la suerte había separado de los leales, vuelven al seno de sus familias, deponen los resentimientos pasados, y ya allí no hay más que españoles" 86 . De manera similar, Juan Bautista Pardo comunicó la "Instrucción para la dirección, buen órden, régimen y gobierno de los jueces y pueblos del distrito de estas provincias", precedidas de una proclama similar a la del mariscal Morillo: contenía una serie de órdenes para reorganizar las provincias venezolanas, de tal manera que se recuperara la organización jurídico-política anterior a 1808. Con respecto al indulto decía:

"XXXIV. Por el Real indulto de S. M. de 24 de Enero de este año, publicado en esta capital en la fecha del dia, quedan indultados todos los reos de infidencia, presentes ó ausentes, procesados ó no procesados, cualesquiera que hayan sido sus opiniones ó sus hechos en las revoluciones pasadas, siempre que se acojan en el término de seis meses a la gracia del perdón. A su consecuencia cesarán todos los procesos que se estén siguiendo con este motivo, y solo continuarán sus trámites, las causas de aquellos individuos que no quieran presentarse a disfrutar el indulto" ${ }^{\prime 87}$.

El avance de las tropas republicanas, sin embargo, habría conseguido que el indulto no tuviera en las provincias venezolanas el impacto deseado. En diciembre de 1817 Morillo escribiría "A los que siguen con las armas en la mano en el partido revolucionario":

"En mi proclama de 21 de septiembre último, con motivo de la publicación del Real Indulto, os anuncié que se iba á abrir una campaña en Venezuela, que no ofrecía indecisión. Mis deseos no eran otros que los de llenar las benéficas intenciones de nuestro amado Soberano, para terminar los males que la guerra civil ocasiona en estos desgraciados países. Yo me lisonjeaba de que la piedad del Rey hubiera tocado vuestro corazón, y que algunos, por lo menos, se hubiesen presentado á gozar de su Real clemencia" $"$.

\footnotetext{
${ }^{85} \mathrm{RAH}$, Sig 9/7650, L 7, f 175.

${ }^{86} \mathrm{RAH}$, Sig 9/7650, L 7, f 175.

${ }^{87}$ BNC, FQ, V 253, P 31, 8.

${ }^{88} \mathrm{RAH}$, Sig 9/7650, L 7, ff 337-338v.
} 
Esta aparente apatía respecto al indulto tuvo como reacción una última ampliación del tiempo de gracia, con lo cual los “alucinados" americanos pudieran desengañarse de su error y volver tranquilos al seno de sus familias. Copias de dicho mensaje fueron enviadas a las diferentes divisiones del ejército, con el fin de que llegaran hasta las tropas insurgentes e incentivaran la deserción en sus filas ${ }^{89}$. El mismo Morillo diría años más tarde:

"Pero el genio del mal reinaba despóticamente en estas desgraciadas comarcas, y el indulto fue insultado, despreciado y burlado por los extraviados. Pocos de estos, residentes en las colonias extranjeras se acogieron a él, y en una gran parte creyéndole efecto del temor y de la impotencia, pasaron a Angostura á forma la expedición con que su jefe Bolivar hizo después la memorable campaña de 1818"90.

El indulto sin embargo sí encontró respuesta en la Nueva Granada. En el cabildo de Marinilla fueron solicitados por lo menos nueve indultos en 1817; mas, la solicitud de ampliar información llevó a algunos a escapar hacia Jamaica, otros fueron condenados al exilio y los restantes lograron obtener el perdón ${ }^{91}$. Justo Cuño ha mostrado para el caso de la provincia de Cartagena que hubo respuestas a los indultos otorgados por Morillo desde 1816; sin embargo, la necesidad que tenían de entregar datos a la justicia para que ampliara las informaciones habría impedido que se concedieran un mayor número de gracias, y en todo caso es de suponer que, al igual que en Marinilla, los acogidos bajo la gracia prefirieran el exilio voluntario en espera de que se calmaran las acciones militares ${ }^{92}$.

En general, la campaña de pacificación combinó el juicio sumario con el perdón general; el castigo se aplicaba de manera expedita buscando el escarmiento de los rebeldes y la contención de los habitantes, para garantizar así "la obediencia y subordinación debida a su soberano", permitiendo sin embargo que disfrutaran de los indultos promulgados por los virreyes y capitanes generales ${ }^{93}$. En su Manifiesto, Morillo defiende su actuación ante las acusaciones de las que su persona estaba siendo objeto en la península, específicamente las realizadas por Antonio Nariño bajo el seudónimo de Enrique Somoyar ${ }^{94}$. El Pacificador

\footnotetext{
${ }^{89}$ RAH, Sig 9/7663, L 20, f 506.

90 Morillo, Pablo, Manifestación que hace a la nación española el teniente general D. Pablo Morillo, Oficina de Don Juan Gutiérrez, Caracas, 1820, p. 28-29.

91 Ramírez Bacca, Renzo \& Marta Ospina Echeverri, Cabildo, política y sociedad, 1810-1821: el caso de la provincia de Antioquia, Universidad Nacional de Colombia, Vicerrectoría General, Comisión para la Celebración del Bicentenario de la Independencia, Bogotá, 2011, p. 48. En la revisión realizada en el Archivo General de la Nación de Colombia sólo se encontró una solicitud de indulto de 1817, en la que un antiguo empleado de la Real Hacienda de Santa Fe solicita ser indultado con el fin de evitar la sentencia de diez años de presidio. La solicitud sólo sería vista en 1819 por el acuerdo extraordinario de la Audiencia de Santa Fe, siendo favorable al reo. AGNC, SC, Miscelánea, L 76, E 20.

92 Cuño Bonito, J., El retorno del rey, Op. Cit., p. 223-224.

93 Cuño Bonito, J., El retorno del rey, Op. Cit., p. 217.

94 Antonio Nariño estuvo preso en Cádiz después de haber sido capturado por las tropas realistas en Pasto, en 1814. Sería liberado por tropas opositoras a Fernando VII, autoexiliándose en la Isla de León para posteriormente dirigirse a
} 
mostró a lo largo de su manifiesto que los triunfos más importantes, aquellos en los que "el enemigo anonadado solo encontraba su salvación en la fuga", venían acompañados de un indulto cuando "en tan oportunas circunstancias mi corazón habló"95; y aunque muchos insurgentes no se acogieron a los indultos, Morillo quería dejar claro que sí hubo una cantidad de ellos que fueron perdonados, así que más que pecar por crueldad lo habría hecho por clemencia:

"Ningún delincuente ha sido condenado sino después de juzgado legalmente por un consejo de guerra, y dictada por el auditor la egecucion de la sentencia. Jamas he hecho otra cosa que dar la sanción que previenen las ordenanzas; y si alguna vez me he separado de estos dictámenes ha sido siempre para perdonar á los reos"96.

En los últimos años de la guerra de independencia, cuando ya era inevitable la victoria republicana, un nuevo indulto real fue promulgado para todos los reinos que aún el monarca consideraba como suyos. Este fue motivado por el tercer enlace matrimonial del monarca realizado con María Josefa Amalia, princesa de Sajonia, siendo promulgado el 9 de noviembre de 181997. Como se mencionó anteriormente, hacía unos meses había sido promulgado el indulto general por el Congreso de Angostura y posteriormente, el 25 de junio de 1821, el Primer Congreso General de Colombia hizo uso de su atribución graciosa como poseedor de la "piedad soberana" para aliviar "la suerte de los desgraciados que gimen bajo el peso de sus crímenes", sin perjudicar a terceros ni a la causa pública, "á fin de poner nuevamente en el camino del honor y de la virtud á todos aquellos que por la debilidad de la naturaleza humana, por falta de luces y por consecuencia de las disensiones civiles hayan sido y estén todavía extraviados de él"98. Los que gemían podían estar tranquilos, la gracia real no había desaparecido, tal vez tan sólo cambió de manos.

\section{El Congreso de Angostura y la Constitución de Cúcuta}

Desde 4 de octubre de 1812 el Congreso de las Provincias Unidas, instalado en la villa de Leiva, será el ente creador de la nueva organización político-administrativa independiente de la monarquía española. Entre tanto, la expansión de la revolución independentista no se encontraría siempre con el favor de los pobladores de las diferentes provincias del Nuevo Reino, por lo que las acciones legislativas tendrían que lidiar con los brotes de contrarrevolución, que serán fortalecidos posteriormente con el ingreso de la expedición

\footnotetext{
Colombia y presentarse a la instalación del Congreso de Cúcuta de 1821. Franco Vargas, Constancio, Rasgos biográficos de los próceres y mártires de la Independencia, vol. I, Imprenta de Medardo Rivas, Bogotá, 1880, p. 51.

${ }^{95}$ Morillo, P., Manifestación, Op. Cit., p. 33.

${ }^{96}$ Morillo, P., Manifestación, Op. Cit., p. 51.

${ }^{97}$ Archivo Histórico Provincial de Zaragoza (AHPZ), Real Audiencia de Aragón (RAA), E 1002, Documento (D) 4.

${ }_{98}$ Cuerpo de leyes de la república de Colombia que comprende todas las leyes, decretos y resoluciones dictados por sus congresos desde el de 1821 hasta el último de 1827, Imprenta de Valentín Espinal, Caracas, 1840, p. 24-25.
} 


\section{Revista Historia y Justicia}

ISSN 0719-4153 revista.historiayjusticia.org

Nº6 - Santiago de Chile, abril 2016, p. 228-257

pacificadora de Pablo Morillo. Los indultos promulgados en este periodo corresponden a atribuciones de los poderes militares, que buscaban detener la insurrección o debilitar al enemigo. El indulto, como se verá en el siguiente apartado, sería un estandarte en la conquista de las poblaciones enemigas y será usado por ambos bandos de igual manera. Sólo la relativa calma, producida después de la victoria republicana sobre los territorios de Colombia y Venezuela, además de la avanzada por el territorio ecuatoriano, permitiría retomar el problema del perdón general.

Tan sólo cinco días después de instalado el Congreso, Juan Vicente Cardoso propuso conceder un indulto general con motivo de la celebración del "augusto congreso", el cual sería aprobado el 25 de febrero de 1819. El encabezado del indulto decía: "Deseando el soberano congreso marcar el día de su augusta instalación con actos de humanidad, piedad y beneficencia, ha acordado indulto general en todo el territorio libre de Venezuela". Dicho perdón iba dirigido especialmente a las tropas enemigas, aunque beneficiaría a la totalidad de los presos en cárceles públicas y cuarteles, con la excepción de "los delitos de espionaje, conspiración contra la patria cometida en el territorio libre, el homicidio voluntario y sodomía"99. La relevancia de esta promulgación radica en que la facultad pasa del ejecutivo, monarca, presidente, gobernador, virrey o comandante, hacia el cuerpo colegiado del Congreso General: así, el presidente podría publicar indultos generales sólo en caso de que el congreso no pudiera reunirse 100 (acta 139, Constitución Política de Venezuela). El Congreso incluso asumió la potestad de conceder indultos particulares, como el solicitado por Francisco Molinar, teniente coronel de infantería de los ejércitos de la República -quien habría sido condenado a muerte por haber ejecutado sin proceso a dos individuos en la provincia de San Miguel-, el cual fue concedido con la condición que retornara al servicio de la república ${ }^{101}$; o el de Juan Gómez, preso por calumnia en el Bajo Apure, al cual se le concedió la gracia "en celebridad de la reunión decretada de los estados de Venezuela y Nueva Granada"102.

El 6 de mayo de 1821 se instaló el Primer Congreso General de la República de Colombia, en cumplimiento de la citación dada por los mismos congresistas en 1819. El día 22 fue propuesto por Bernardino Tobar el primer indulto general para celebrar la instalación del congreso, dejando claro con ello "el interés de atraer los muchos desertores que andan fugitivos, y otros objetos de clemencia" ${ }^{103}$. Azuero consideró que en lugar de

\footnotetext{
99 Actas 6 y 10. Cortázar, Roberto \& Luis Augusto Cuervo (eds.), Actas del Congreso de Angostura 1819-1820, Biblioteca de la Presidencia de la República, Bogotá, 1988, http://www.bdigital.unal.edu.co/7847/, consultado el 22 de marzo de 2015.

100 Acta 139, "Constitución Política de Venezuela", Cortázar, R. \& Cuervo, L., Actas del Congreso, Op. Cit.

101 Acta 105, Cortázar, R. \& Cuervo, L., Actas del Congreso, Op. Cit.

102 Acta 233, Cortázar, R. \& Cuervo, L., Actas del Congreso, Op. Cit.

103 Acta 21, Actas del Congreso de Cúcuta 1821, Biblioteca de la Presidencia de la República, Bogotá, 1989.
} 
promulgarse por la plenaria del congreso debería formarse una comisión, para que dicha promulgación no conllevara el rechazo por parte de los "verdaderos patriotas".

Las actas del Congreso dejan ver una ligera oposición, por parte de algunos legisladores que consideraban que otorgar un indulto a los "enemigos de la causa americana" era un acto de injusticia con los "defensores de la República", ya que "estos monstruos por el momento parecían agradecidos al gobierno, pero que después clavaban con su mano el puñal en nuestros pechos"104. A pesar de la oposición el indulto, con motivo de la instalación del congreso fue aprobado por unanimidad, y se determinó además que tendría fuerza de ley. Este decreto tendría la particularidad de señalar que los esclavos desertores que se acogieran a la gracia tendrían la posibilidad de "volver al dominio de sus amos o al servicio de las armas"105. Lo anterior generó una discusión relacionada con la posibilidad de ofrecer la libertad después de un tiempo de servicio, lo que sin embargo no representó una modificación a la propuesta original.

El indulto mencionado incluyó la siguiente cláusula: "Serán comprendidos también en este indulto los enemigos de la independencia que se presentaren a jurar fidelidad a la República, o se les concederá pasaporte para salir del territorio dentro de un término proporcionado". Pero dicho juramento, una fórmula de cierta manera copiada de los perdones reales, no consiguió disipar las dudas relativas a la posible inclusión de enemigos de la independencia. Por ejemplo, Joaquín Borrero consideraba que el indulto debería limitarse a los desertores americanos, puesto que los españoles verían en esto un acto de "docilidad" del gobierno ${ }^{106}$.

Finalmente, el Congreso dejaría claro que sería el único encargado de otorgar indultos generales. La primera constitución política de la república de Colombia dejó esto plasmado en el artículo 55, inciso 20, relativo a las funciones exclusivamente propias del congreso: "Conceder indultos generales cuando lo exija algún grande motivo de conveniencia pública"107. Pero también se atribuyó la gracia de conceder perdones particulares a través de la "Comisión de peticiones", una división que trataba la gran cantidad de quejas y reclamaciones dirigidas a los funcionarios del congreso y autoridades de la república, entre las que se contaban los indultos por las penas que se habían juzgado en el marco de la guerra revolucionaria.

\footnotetext{
104 Acta 27, Actas del Congreso de Cúcuta 1821.

105 Acta 27, Actas del Congreso de Cúcuta 1821.

106 Acta 36, Actas del Congreso de Cúcuta 1821.

107 Acta 150, Actas del Congreso de Cúcuta 1821.
} 


\section{Consideraciones finales}

Más allá del evidente desorden social causado por los enfrentamientos, rastrear la totalidad de solicitudes de indulto en el ínterin revolucionario se vuelve una tarea casi imposible. En primer lugar muchas solicitudes se llevaron a cabo por mecanismos expeditos, vía oral, con autoridades militares de ambos bandos. En segundo lugar, el traslado de la Audiencia de Santa Fe a Panamá habría conllevado una mayor dificultad para hacer llegar las solicitudes de indulto a las autoridades regalistas. En tercer lugar, la mayoría de las solicitudes que se hicieran a las autoridades judiciales revolucionarias sufrieron el mismo destino que éstas: fueron arrasadas por las tropas realistas o simplemente dejadas a un lado cuando se configuró la organización del poder judicial, en 1821. Finalmente, muchas de estas solicitudes simplemente desaparecieron, como otras tantas causas judiciales que se iniciaron entre 1808 y 1814.

Justo Cuño Bonito y Renzo Ramírez Bacca han mostrado cómo, a nivel local, dichas solicitudes de indulto se realizaron con diferentes intereses. Como sea, es casi imposible determinar el impacto real que causaron las declaraciones de perdón otorgadas por las autoridades regalistas y revolucionarias antes de 1821. Las peticiones de indulto seguirían siendo una constante durante el siglo XIX, como muestra Joshua Rosenthal en su estudio de los indultados en la Guerra de los Supremos (1839-1842) y de la revolución de Melo en 1854, y fueron decayendo a la par de la abolición de la pena de muerte en las diferentes legislaciones federales de la segunda mitad del siglo XIX ${ }^{108}$. En todo caso, éste sigue siendo un tema que debe tratarse de manera más amplia, especialmente si se desea comprender cómo se conecta con las amnistías decretadas durante los diferentes armisticios del siglo XX colombiano.

Este trabajo tan sólo plantea el problema del indulto en la transición de monarquía a república. En este sentido, es un análisis institucional a nivel macro. Sin embargo, se deja en evidencia dos grandes lagunas: por una parte, la falta de estudios regionales relacionados con el indulto en el contexto de la guerra revolucionaria, y ello, a pesar de los trabajos de Justo Cuño, Marta Ospina y Renzo Ramírez, que ayudan a ampliar esta perspectiva. En realidad carecemos aún de información más detallada de otras regiones. La segunda laguna que pudo identificarse con la realización de este trabajo es la relativa al perdón particular, $y$ en especial, el otorgado por jueces ordinarios. ¿Es posible identificar una economía de la gracia en el Nuevo Reino? Pero sobre todo, ¿el perdón en las causas criminales puede identificarse aún en la época republicana?

108 Rosenthal, Joshua M., “The 'Indultados' of Tescua: Criminal Rebellion and Judicial Reckoning during the War of the Supremes", Anuario Colombiano de Historia Socialy de la Cultura, Bogotá, vol. 39, n², 2012, p. 150-152. 
Sin duda una exploración a las posibles peticiones individuales de perdón elevadas a la presidencia de la Audiencia, al virrey e incluso al mismo monarca pueden brindar luces a dicho problema, de la misma manera que la revisión de las actuaciones de los gobernantes provinciales y municipales durante la primera mitad del siglo XIX, quienes conservaron las atribuciones de justicia hasta bien entrado el siglo.

\section{Fuentes}

\section{Inéditas}

Archivo General de la Nación de Colombia, Bogotá

Sección Colonia, Asuntos criminales, Legajos 2, 6, 10, 46, 50, 67, 70, 76, 78, 90, 138, 139, 145 y 148.

Sección Colonia, Miscelánea, Legajos 68, 76 y 122.

Sección República, Legajo 46 y 75.

Sección Estado, Legajo 57, Caja 74.

Archivo Histórico Provincial de Zaragoza

Real Audiencia de Aragón, Expediente 1002, Documento 4.

Biblioteca Nacional de Colombia, Bogotá

Fondo Quijano, Volumen 253, Pieza 30.

\section{Publicadas}

"Actas del Colegio Electoral y Constituyente de Antioquia", en Actas de los colegios electorales y constituyentes de Cundinamarca y Antioquia, 1811-1812, Colección Bicentenario 7, Universidad Externado de Colombia, Universidad Industrial de Santander, Bogotá, Bucaramanga, 2010, parte II, p. 89-274.

Actas del Congreso de Cúcuta 1821, Biblioteca de la Presidencia de la República, Bogotá, 1989, 280 p.

Actas del serenísimo colegio Constituyente y electoral de la Provincia de Cundinamarca: congregado en su capital la ciudad de Santafé de Bogotá para formar y establecer su constitución, Imprenta Real de Santaf de Bogotá, Bogotá, 1811, 165 p.

Álvarez Posadilla, Juan, Práctica criminal por principios, o modo y forma de instruir los procesos criminales de las causas de oficio de la justicia contra los abusos introducidos, vol. II, Imprenta de la viuda de Ibarra, Madrid, 1797, 496 p.

Beccaria, Cesare, Tratado de los delitos y de las penas, traducido por Juan Antonio de las Casas, por D. Joachín Ibarra, Madrid, 1774, 482 p.

Bolívar, Simón, Escritos del libertador, vol. VI, Sociedad Bolivariana de Venezuela, Caracas, 1969, 522 p.

Bolívar, Simón, Proclamas de Simón Bolivar libertador de Colombia, D. Appleton y compañía, Nueva York, 1853, 73 p.

Colón de Larriátegui, Félix, Juzgados militares de España y sus Indias, por Ibarra, Madrid, 1817, 624 p.

Constitución de Cundinamarca: su capital Santafé de Bogotá, Imprenta patriótica de don Nicolás Calvo y Quixano, Bogotá, 1811, 47 p.

Constitución de la República de Cundinamarca reformada por el Serenísimo Colegio Revisor y Electoral, Imprenta de Don Bruno Espinosa, Santafé de Bogotá, 1812, 59 p. 


\section{Revista Historia y Justicia}

ISSN 0719-4153 revista.historiayjusticia.org

Nº6 - Santiago de Chile, abril 2016, p. 228-257

Constitución de Mariquita, Imprenta del Estado, Santafé de Bogotá, 1815, 44 p.

Constitución del Estado de Antioquia sancionada por los representantes de toda la Provincia y aceptada por el pueblo el tres de mayo del año de 1812, Imprenta de Don Bruno Espinosa, Santafé de Bogotá, 1812, 73 p.

Constitución del Estado libre de Neiva revisada en el año de 1815, Imprenta San Bernardo, Bogotá, 1914, 49 p.

Constitución politica del Estado de Cartagena de Indias, Imprenta del ciudadano Diego Espinosa, Cartagena, 1812, 66 p.

Constitución provisional de Antioquia, revisada en convención de 1815, Imprenta del Gobierno, Medellín, 1815, 48 p.

Cornejo, Andrés, Diccionario histórico y forense del Derecho Real de España, por D. Joachin Ibarra, Madrid, 1779, 628 p.

Cortázar, Roberto \& Luis Augusto Cuervo (eds.), Actas del Congreso de Angostura 1819-1820, Biblioteca de la Presidencia de la República, Bogotá, 1988, http://www.bdigital.unal.edu.co/7847/.

Cuerpo de leyes de la república de Colombia que comprende todas las leyes, decretos y resoluciones dictados por sus congresos desde el de 1821 hasta el último de 1827, imprenta de Valentín Espinal, Caracas, 1840, 646 p.

Edicto para manifestar al público el indulto general, concedido por nuestro Catholico Monarca el Señor Don Carlos III. A todos los comprehendidos en las revoluciones acaecidas en el año pasado de mil setecientos ochenta y uno, Santafé de Bogotá, 1782, 19 p.

Franco Vargas, Constancio, Rasgos biográficos de los próceres y mártires de la Independencia, vol. I, Imprenta de Medardo Rivas, Bogotá, 1880, 288 p.

Gutiérrez, José Marcos, Práctica criminal de España, Oficina de Don Benito García y Compañía, Madrid, 1804, 444 p.

Hernández de Alba, Guillermo (ed.), Archivo Nariño, Biblioteca de la Presidencia de la República, Santafé de Bogotá, 1990, 423 p.

Hevia de Bolaños, Juan de, Curia Pbilipica, edición facsímil del original de 1790, Lex Nova, Valladolid, 1989, 599 p.

Morillo, Pablo, Manifestación que hace a la nación española el teniente general D. Pablo Morillo, Oficina de Don Juan Gutiérrez, Caracas, 1820, 59 p.

"Proyecto de constitución de la Provincia de Popayán, formado por el serenísimo colegio electoral y constituyente del presente año de 1814", Boletín Histórico del Valle, Cali, n49-53, 1958, p. 35-61.

Real Academia de la Historia, Madrid, España, Signaturas 9/7650, 9/7654 y 9/7663.

Recopilación de las leyes de los reinos de las indias, 4 vols., por Julian de Paredes, Madrid, 1681. http:// fondosdigitales.us.es/fondos/libros/752/14/recopilacion-de-leyes-de-los-reynos-de-las-indias/.

Solórzano Pereyra, Juan de, Politica Indiana, Henrico y Cornelio Verdussen, Amberes, 1703, 660 p.

\section{Bibliografía}

Agüero, Alejandro, Castigar y perdonar cuando conviene a la República: la justicia penal de Córdoba del Tucumán, siglos XVII y XVIII, Centro de Estudios Políticos y Constitucionales, Madrid, 2008, 488 p.
, "Clemencia, perdón y disimulo en la justicia criminal del Antiguo Régimen: Su praxis en Córdoba del Tucumán, siglos XVII y XVIII", Revista de bistoria del derecho, Buenos Aires, n³2, 2004, p. 33-82. 
Annino von Dusek, Antonio, "Voto, tierra, soberanía: Cádiz y los orígenes del municipalismo mexicano", en Guerra, FrançoisXavier (ed.), Revoluciones hispánicas: independencias americanas y liberalismo español, Universidad Complutense, Madrid, 1995, p. 269-292.

"Revoluciones hispanoamericanas. Problemas y definiciones", en González Bernaldo de Quirós, Pilar (coord.), Independencias iberoamericanas. Nuevos problemas y aproximaciones, Fondo de Cultura Económica, Buenos Aires, 2015, p. 37-52.

Carneiro, Sarissa, "La clemencia del príncipe: su representación alegórica en emblemas y empresas de España y América colonial", Revista Chilena de Literatura, Santiago, n85, 2013, p. 75-100.

Cuño Bonito, Justo, El retorno del rey: el restablecimiento del régimen colonial en Cartagena de Indias (1815-1821), Universitat Jaume I, Castelló de la Plana, 2013, 481 p.

Escobar Villegas \& Juan Camilo \& Adolfo León Maya Salazar, "Ilustrados, leyes penales, control social y administración de justicia durante la época de las revoluciones modernas en nueva Granada: una mirada desde la obra de Gaetano Filangieri", Revista Historia de la Educación Latinoamericana, Tunja, $\mathrm{n}^{\circ}$ 9, 2007, p. 141-80.

Garriga, Carlos, "Orden jurídico e independencia política: Nueva España, 1808México, 1821", en Annino, Antonio (coord.), La revolución novohispana, 1808-1821, Fondo de Cultura Económica, México, 2010, p. 35-124.

Gutiérrez Ardila, Daniel, Un nuevo reino: geografía politica, pactismo y diplomacia durante el interregno en Nueva Granada, 1808-1816, Universidad Externado de Colombia, Bogotá, 2010, 637 p.

Hespanha, António Manuel, La gracia del derecho: economía de la cultura en la edad moderna, Centro de Estudios Constitucionales, Madrid, 1993, 351 p.
"La senda amorosa del derecho. Amori y iustitia en el discurso jurídico moderno", en Petit, Carlos (ed.) Pasiones del jurista: amor, memoria, melancolia, imaginación, Centro de Estudios Constitucionales, Madrid, 1997, p. 23-73.

Lalinde Abadía, Jesús, "El régimen virreinosenatorial en Indias", Anuario de Historia del Derecho Español, Madrid, vol. XXXVII, 1967, p. 5-244.

Levaggi, Abelardo, "Las instituciones de clemencia en el Derecho penal rioplatense", $I V$ Congreso del Instituto Internacional de Historia del Derecho Indiano, 1976, p. 243-98.

Martínez Garnica \& Armando \& Quintero Montiel, Inés Mercedes, "La formación de los Estados republicanos en la Nueva Granada y Venezuela", Ayer. Revista de historia contemporánea, Madrid, n74, 2009, p. 77-105.

Mercado, Jorge, Campaña de Invasión del Teniente General don Pablo Morillo 1815-1816: El régimen del terror, Ediciones LAVP, Bogotá, 2015, 183 p.

Montoya Gómez, María Victoria, "Los jueces y los desordenados: la administración de justicia y los esfuerzos por ordenar vistos a través de las relaciones ilícitas. El caso de la ciudad de Antioquia, 1750-1809", Tesis de doctorado en Historia, Universidad Nacional Autónoma de México, Ciudad de México, México, 2013.

"Castigo y perdón: el movimiento comunero. Nuevo Reino de Granada, 1781", Mouseion, Canoas, $\mathrm{n}^{\circ} 18,2014$, p. 35-53.

Morelli, Federica, "Tras las huellas perdidas de Filangieri: nuevas perspectivas sobre la cultura política constitucional en el Atlántico hispánico", Historia contemporánea, Bizakia, n³3, 2006, p. 431-462.

Ortego Gil, Pedro, Entre jueces y reos. Las postrimerias del Derecho penal absolutista, Dykinson, Madrid, 2015, $562 \mathrm{p}$. 
Ots Capdequí, José María, Las instituciones del Nuevo Reino de Granada al tiempo de la independencia, Consejo Superior de Investigaciones Científicas, Madrid, 1958, 396 p.

Ramírez Bacca, Renzo \& Marta Ospina Echeverri, Cabildo, politica y sociedad, 1810-1821: el caso de la provincia de Antioquia, Universidad Nacional de Colombia, Vicerrectoría General, Comisión para la Celebración del Bicentenario de la Independencia, Bogotá, 2011, 97 p.

Rodríguez Flores, María Inmaculada, El perdón real en Castilla (siglos XIII-XVIII), Universidad de Salamanca, Salamanca, 1971, 284 p.

Rosenthal, Joshua M., “The 'Indultados' of Tescua: Criminal Rebellion and Judicial Reckoning during the War of the Supremes",
Anuario Colombiano de Historia Social y de la Cultura, Bogotá, vol. 39, n², 2012, p. 131-156.

Thibaud, Clément, Repúblicas en armas: los ejércitos bolivarianos en la guerra de Independencia en Colombia y Venequela, Instituto Francés de Estudios Andinos y editorial Planeta, Bogotá, 2003, 571 p.

Tomás y Valiente, Francisco, "De la administración de justicia al poder judicial", en Tomás y Valiente, Francisco, Obras completas, Centro de Estudios Políticos y Constitucionales, Madrid, 1997, parte VI, p. 4169-4182.

, "El perdón de la parte ofendida en el derecho penal castellano (Siglos XVI, XVII y XVIII)", en Tomás y Valiente, Francisco, Obras completas, Centro de Estudios Políticos y Constitucionales, Madrid, 1997, parte IV, p. 2885-2933. 